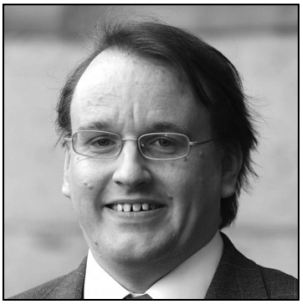

Andrew Steven

Scottish Law Commissioner

Senior Lecturer, University of Edinburgh

\title{
Developments in the Scottish Law of Land Registration
}

\section{Introduction}

This article considers the background to the recently enacted Land Registration etc. (Scotland) Act 2012, which is due to come fully into force in 2014. A useful starting point may be to draw some general comparisons between Scotland and Estonia, with the aid of the following table. ${ }^{{ }_{1}}$

\begin{tabular}{|c|c|c|}
\hline & Scotland & Estonia \\
\hline Population & $5 \cdot 3$ million & 1.3 million \\
\hline Area & $78,387 \mathrm{~km}^{2}$ & $45,227 \mathrm{~km}^{2}$ \\
\hline $\begin{array}{l}\text { Commencement of } \\
\text { public land registration }\end{array}$ & 1617 & $\begin{array}{l}1747 \text { (though discontinued } \\
\text { in the Soviet era) }\end{array}$ \\
\hline $\begin{array}{l}\text { Percentage of area } \\
\text { in Land Register }\end{array}$ & $\begin{array}{l}23 \% \text { (almost all the rest } \\
\text { is in the Register of Sasines) }\end{array}$ & $\begin{array}{l}\text { 61\% (land held by the state does } \\
\text { not have to be registered; } \\
90 \% \text { is in cadastre systems) }\end{array}$ \\
\hline Registered title units & $\begin{array}{l}2.3 \text { million ( } 56 \% \text { in the Land Register } \\
\text { and } 44 \% \text { in the Register of Sasines) }\end{array}$ & 969,000 \\
\hline $\begin{array}{l}\text { Parts of a Land Register } \\
\text { entry }\end{array}$ & $\begin{array}{l}\text { A. Property (mapped) } \\
\text { B. Proprietorship } \\
\text { C. Securities } \\
\text { D. Burdens }\end{array}$ & $\begin{array}{l}\text { 1. Cadastral information } \\
\text { 2. Proprietorship } \\
\text { 3. Burdens } \\
\text { 4. Securities }\end{array}$ \\
\hline
\end{tabular}

In broad terms, the table simply shows that Scotland is a larger country than Estonia: with a population four times greater and being one and a half times larger by area. It also has more than double the number of registered title units. With this in mind, it is perhaps difficult not to think about 18 September 2014. On that date, there will be a referendum in Scotland on independence from the United Kingdom. Perhaps the main argument against separation is that Scotland is in a better position as part of a larger country ${ }^{{ }^{2}}$, yet Scotland is considerably bigger than Estonia.

1 The main sources of the information here are http://eulis.eu/service/countries-profile/estonia/ and http://www.ros.gov. $\mathrm{uk} / \mathrm{pdfs} /$ landmasscoveragereport2012.pdf (most recently accessed on 29.1.2014).

$2 \quad$ See http://www.bettertogether.net/ (most recently accessed on 29.1.2014). 
If one examines the last part of the table, a marked similarity between the format of the Estonian and Scottish land registers can be seen. Accordingly, there may indeed be things that these two countries can learn from each other.

\section{The Registration Act 1617}

Scotland was one of the first countries in the world to introduce legislation on land registration. ${ }^{*}$ It did so in 1617 , more than a hundred years before Estonia did. ${ }^{*}$ The Registration Act of that year, written in old Scots, provides the following:

Oure Souerane Lord Considdering the gryit hurt sustened by his Maiesties Liegis by the fraudulent dealing of pairties who haveing annaliet their Landis and ressauit gryit soumes of money thairfore [...] FOR remedie whereoff and of the manye Inconvenientis whiche may ensew thairupoun HIS Maiestie with aduyis and consent of the estaittis of Parliament statutes and ordanis That thair salbe ane publick Register. ${ }^{*}$

The fundamental reason for the legislation was individuals selling the same piece of land more than once. Stopping fraud such as this necessitated a register, and that register had to be a public one. Section 55 (1) of the Estonian Law of Property Act is to a similar effect. ${ }^{*} 6$

The 1617 Act established a register known as the Register of Sasines. ${ }^{.7}$ It is run by a government department known as Registers of Scotland. ${ }^{*} 8$ This is in contrast with Estonia, where the register is under court supervision. The head of the department or chief registrar is known as the Keeper of the Registers of Scotland (or more commonly as 'the Keeper'). The name 'Sasine' comes from the now obsolete ceremony of 'giving Sasine', wherein the transferor had to hand over symbols of the land to the transferee as part of the transfer process. ${ }^{*} 9$ Those symbols were earth and stone.

The key features of the Register of Sasines are the following. First and most importantly, it is a register of deeds rather than a register of title. In effect, it is a warehouse; one that contains millions of deeds. To be more accurate, one could say that it contains millions of copies of deeds. When a deed of transfer is sent to the register, a copy is made of it and the original returned to the transferee. In the old days, the copy was made with quill and ink. More recently, photocopying has become available, and now, of course, there is digital scanning.

The Register of Sasines is organised into 33 local areas, called counties. The register can be searched within a particular county for the relevant deeds by a) person and b) the address of the property. However, the register itself does not directly state who the owner is: the relevant deeds have to be interpreted. There is also no national map or cadastre. Indeed, it became possible to register deed plans only from $1924 .{ }^{*} 10$

The Register of Sasines is a 'negative' registration system. In other words, the validity of a transfer depends entirely on the validity of the deed being registered. For example, a deed of transfer granted by someone who is not the owner of the land in question will be ineffective. So too will a deed granted by

See http://www.ros.gov.uk/public/about_us/history.html (most recently accessed on 29.1.2014).

4 Public land registries were introduced in Estonia in 1747. See M. Kaing. Real property cadastre in Estonia. - V. Parsova, V. Gurskiene, M. Kaing (eds). Real Property Cadastre in Baltic Countries. 2012, p. 11. Available at http://www2.llu.lv/ homepg/zigk/materiali/V.Parsova,\%20V.Gurskiene,\%20\%20M.Kaing.\%20Real\%2oProperty\%20Cadastre\%20in\%20 Baltic\%20Countries.pdf (most recently accessed on 29.1.2014).

5 In modern English: 'Our Sovereign Lord considering the great hurt sustained by His Majesty's people by the fraudulent dealing of parties who, having transferred their land and received great sums of money therefor [...] for remedy whereof and of the many inconveniences which may ensue thereupon, His Majesty with the advice and consent of the estates of Parliament sets forth a statute and ordains that there shall be a public register.'

6 See P. Pärna. The Law of Property Act-Cornerstone of the Civil Law Reform. - Juridica International 2001, p. 93.

7 For an overview, see G.L. Gretton, A.J.M. Steven. Property, Trusts and Succession, 2nd ed. Haywards Heath: Bloomsbury Professional 2013, paragraphs 6.8-6.13.

8 See http://www.ros.gov.uk/ (most recently accessed on 29.1.2014).

9 See K.G.C. Reid. The Law of Property in Scotland. Edinburgh: Law Society of Scotland / Butterworths 1996, paragraph 89 (referring to G.L. Gretton).

10 Conveyancing (Scotland) Act 1924, Section 48. 
someone who lacks legal capacity to do so. Also, there is no protection for someone relying on the register in good faith. Finally, no state indemnity/compensation system can be called upon if something goes wrong.

Conveyancing in the Register of Sasines is complex. It can be done only by experts-in practice, trained lawyers-because it is necessary to know how to find the relevant deeds and how to check them correctly. Therefore, pressure grew in the 1960 s and 1970 for adoption of a simpler system. ${ }^{* 11}$

\section{The Land Registration (Scotland) Act 1979}

That pressure led to the Land Registration (Scotland) Act 1979, which was enacted in the dying days of the government that preceded Margaret Thatcher's coming to power. The 1979 Act established the Land Register of Scotland. ${ }^{*}$ It too is run by Registers of Scotland.

Under the 1979 Act, land is transferred from the old register to the new as and when the land is sold for the first time after the new register's coming into operation. ${ }^{*} 13$ According to the latest figures, $56 \%$ of title units are now in the Land Register, with $44 \%$ still in the Register of Sasines. Clearly, there is still a long way to go before completion of the transition from the old register to the new one.

The key features of the Land Register under the 1979 Act are the following. Firstly, it is based on the English Land Register and English legislation. This was where things started to go wrong, as Scottish property law is rather different from that in England. ${ }^{* 14}$ Although Scotland is perhaps most famous in European private-law terms for being a mixed legal system, its property law is strongly civil in character. Secondly, the Land Register is a register of title, of similar nature to the Estonian Land Register. Registers of title were a development of the nineteenth century, and there are three main families of such registers: a) the Germanic systems, b) the Torrens systems ${ }^{*}{ }^{15}$, and c) the English systems. ${ }^{*} 16$ In all of these, the register directly states who the owner is. In addition, the Land Register is divided into the same local areas as the Register of Sasines. Fourthly, each property has a title sheet rather like one of the deed cards in the board game Monopoly. Each title sheet has a unique title number. For example, the title number for Edinburgh Castle is MID1 ('MID' is the abbreviation for 'Midlothian'). The title sheet has four parts, per the table on the first page of the article. Part A, the Property Section, identifies the property relative to a national map. Mapping is a major innovation in comparison with the Register of Sasines. Part B, the Proprietorship Section, identifies the land-owner. Part C is the Charges Section, identifying any mortgages (or 'standard securities', if one wishes to use the correct technical term). Finally, part D, the Burdens Section, addresses any servitudes or other encumbrances. A fifth feature is that the register itself is entirely electronic.

Sixthly, in another huge change relative to the Register of Sasines, the Land Register is a 'positive' system of registration with immediate indefeasibility. In other words, the validity of an entry in this register does not depend on the validity of the underlying deed. Imagine that Brait grants a deed transferring five fields to Maarja when, in fact, he owns only four of them and a mistake is made in the plan attached to the deed. The fifth field is owned by Triin. Maarja acquires ownership of all five fields if the Keeper registers her as the owner, even although Brait owned only four of them. ${ }^{*}{ }^{17}$ This effect has become known as the Keeper's 'Midas touch', after King Midas, who turned everything he touched into gold. Under the 1979 Act, everything that the Keeper touches becomes valid. ${ }^{*} 18$ Maarja's acquisition of ownership is immediate, taking place as soon as registration is performed.

$11 \quad$ G.L. Gretton and A.J.M. Steven (see Note 7), paragraph 6.14.

12 Land Registration (Scotland) Act 1979, Section 1.

13 The Land Register was brought into operation in stages by county, with the process beginning in 1981 and with the final counties being added in 2003 .

14 See, for example, K.G.C. Reid (see Note 9), paragraph 2: 'A lawyer trained in Scotland can without difficulty (other than linguistic difficulty) read and understand a book about the law of property in Germany [...]. But he is likely to be perplexed and bewildered by a book on the law of property in England.'

15 Notably Australia and New Zealand.

16 E. Cooke. The New Law of Land Registration. Oxford: Hart Publishing 2003, p. 11.

17 Land Registration (Scotland) Act 1979, Section 3(1)(a).

18 Scottish Law Commission. Discussion paper on land registration: Void and voidable titles. (paper 125, 2004), paragraph 5.34. Available at http://www.scotlawcom.gov.uk/publications/ (most recently accessed on 29.1.2014). 
What can happen if mistakes such as this occur? The 1979 Act provides for a process called rectification. ${ }^{*} 19$ Utilising it, Triin as the former owner of the fifth field can apply to have the register rectified, against Maarja's interests. However, as with the English legislation that influenced the 1979 Act, rectification is generally not available against a proprietor in possession without that person's consent. Accordingly, if Triin happened to be abroad while the transfer took place and Maarja took possession of the extra field in good faith, it might be impossible to rectify against her in this manner.

Finally, the 1979 Act offers a system of state indemnity (compensation) when someone suffers a loss through the Keeper rectifying or refusing to rectify the register. ${ }^{* 20}$ In the above example, Triin would be entitled to compensation if the register does not get rectified in the end.

It became apparent as the 1980 s and 1990 os progressed that the new system, while in many ways being a great improvement on the Register of Sasines, was defective. The 1979 Act itself is inadequate and all too brief. It extends to only 30 sections, and some of these are on other topics. Moreover, in the words of Professor George Gretton, it 'has all the intellectual sharpness of a mashed potato'. ${ }_{21}$

At a practical level too, the legislation was not working: land was moving from the old register to the new register too slowly. As has already been mentioned, about $44 \%$ of titles are still in the old register rather than the new one. Indeed, only $23 \%$ of Scottish land mass is covered by the new register. This is because land held by public bodies or estates owned by aristocratic families are rarely sold.

A further problem with the 1979 Act is that immediate defeasibility is not very consistent with underlying principles of property law such as the nemo plus iuris ad alium transferre potest quam ipse haberet rule (which one can translate as 'no-one can give what he does not have'). Reference can be made again to the example of Brait, Maarja, Triin, and the fifth field. What the 1979 Act does is create its own set of property-law rules, leading to what the Scottish Law Commission has called 'bijuralism'. ${ }^{22}$ The result is incredibly complex.

A final difficulty is that possession is used rather too bluntly to protect a registered proprietor. Why should Triin, who happened to be away from her field for a matter of weeks, lose out? In fact, there was a case in Glasgow that involved competing parties hiring locksmiths to change the locks on the door to a flat so that they could assert that they were in possession. ${ }^{*}{ }^{23}$ Another case involved divers moving bollards in a river to assert possession of the relevant part of it on behalf of owners of other land who were supermarkets-one of which had an interest in erecting a bridge over the river. ${ }^{* 24}$

On account of all the defects, the Keeper of the Registers of Scotland asked the Scottish Law Commission to review the 1979 Act. A public body that advises the Scottish Government on law reform, the Scottish Law Commission has five commissioners and various legal and administrative support staff. The project focusing on the 1979 Act was initiated by the property-law commissioner of the time, Professor Kenneth Reid. His term as a commissioner concluded in 2005, and it fell to his successor-the above-mentioned Professor Gretton-to complete the job. Throughout the project, the Scottish Law Commission had the benefit of a member of staff from Registers of Scotland being seconded to work for it. The commission eventually published a lengthy two-volume report, in 2010, which included a new draft Land Registration (Scotland) Bill. ${ }^{*} 25$

The report was accepted in substantial part by the Scottish Government, and legislation based on the draft bill was brought before the Scottish Parliament. This entered into law as the Land Registration etc. (Scotland) Act 2012.

9 Land Registration (Scotland) Act 1979, Section 9.

$20 \quad$ Ibid., Section 12.

21 In his case comment on Kaur v. Singh. See 1997 SCLR 1075 at 1085. See also Short's Tr. v. Keeper of the Registers of Scotland, 1996 SC (HL) 14 at 26: 'Nobody could accuse the Act of being well drafted.' But the blame should not be heaped on the draftsmen. The underlying policy was not thought through sufficiently well. See MRS Hamilton Ltd $v$. Keeper of the Registers of Scotland, 2000 SC 271 at 275 per Lord President Rodger.

22 Scottish Law Commission (see Note 18), paragraph 1.11.

23 Kaur v. Singh, 1997 SCLR 1075.

24 Safeway Stores plc v. Tesco Stores Ltd, 2004 SC 29.

25 Scottish Law Commission, Report on Land Registration (SLC 222, 2010). Available at http://www.scotlawcom.gov.uk/ publications/. 


\section{The Land Registration etc. (Scotland) Act 2012}

The reason that the 2012 Act is scheduled to come into force in late 2014 is that there needs to be a transitional period for Registers of Scotland, solicitors, and others to prepare. ${ }^{{ }^{2} 26}$ One can note several key features of the new legislation. Firstly, it is a much longer and more sophisticated piece of legislation than the 1979 Act, extending as it does to 124 sections. This makes it of a very similar length to the Estonian Land Register Act of 1993. Secondly, its underlying theme is evolution rather than revolution. ${ }^{* 27}$ The Land Register continues as an electronic mapped register of title. Thirdly, the 2012 Act enables the process of moving over from the Register of Sasines to the Land Register to be sped up. ${ }^{* 28}$ All transfers of land must be registered, not just transfers upon sale. ${ }^{* 2}$ Where there is no transfer, the owner of the land may apply for voluntary registration. ${ }^{*} 30$ In addition, from a date yet to be decided by the Government, the Keeper will be able to move land from the old register to the new register compulsorily. ${ }^{*}{ }^{31}$

Fourthly, immediate defeasibility and, along with it, the Midas touch and bijuralism are eliminated. Let us return to our example. Maarja would not become the owner of the fifth field, for the 2012 Act introduces deferred defeasibility, rather akin to the position in Estonia ${ }^{*} 32$ and in Germany. ${ }^{*} 3$ This means that if Kaspar, a third party acting in good faith, were to purchase the field from Maarja, he would acquire ownership because he is entitled to rely on the register. ${ }^{*} 34$

Fifthly, the role of possession is reduced. The mere fact that someone registered as proprietor is in possession of the land does not entail that person is protected. Yet possession does play a role in relation to defeasibility. If we go back to our example once again, Kaspar will be protected from rectification only if the total time for which he and predecessor Maarja have been in possession of the field is at least a year. ${ }^{*} 35$ Accordingly, if the initial transfer from Brait to Maarja and then the transfer onward to Kaspar took place in the course of the one summer, while Triin, the original owner of the fifth field, was in Salzburg, Triin would be able to have the register rectified. Kaspar's remedy would be compensation from the Keeper. What the 2012 Act is doing here is making a choice with a division between who gets 'the mud' and who gets 'the money'. ${ }^{3} 36$

Sixthly, the system of indemnity is reformed and replaced with what is known as 'the Keeper's warranty'. The 2012 Act provides that 'the Keeper, in accepting an application for registration, warrants to the applicant that, as at the time of registration, the title sheet to which the application relates (a) is accurate [...] in so far as it shows an acquisition, variation or discharge in favour of the applicant'. ${ }^{37}$ Therefore, if the Keeper registers Maarja as the owner of the fifth field and then rectifies the register upon Triin turning up within a year to contest this, compensation must be paid to Maarja. This is the position when Maarja is in good faith. If she is in bad faith, compensation is excluded. ${ }^{*} 8$ It is worth emphasising that the Keeper's duty to pay compensation is more extensive than is generally seen in the Germanic systems; there, compensation is normally payable only for mistakes that are directly the registrar's fault.

Finally, the 2012 Act introduces 'advance notices'. In this there was influence from the German Vormerkungen ${ }^{*} 39$ as much as from English law. ${ }^{*} 40$ At the moment, problems that arise in Scotland in the time between settlement of the sale transaction and registration are covered by the selling solicitor's indemnity

\footnotetext{
See http://www.ros.gov.uk/2012act/background.html (most recently accessed on 29.1.2014). For an overview, see G.L. Gretton and A.J.M. Steven (see Note 7), paragraphs 6.21-6.79.

7 Scottish Law Commission (see Note 25), paragraph 1.7.

Ibid. (see Note 25), Part 33.

Land Registration etc. (Scotland) Act 2012, Sections 48 and 50.

Ibid., Sections 27-28.

Ibid., Section 29.

Estonian Law of Property Act 1993, Section 56.

Bürgerliches Gesetzbuch (BGB), Section 892.

Land Registration etc. (Scotland) Act 2012, Section 86.

Ibid., Section 86(3)(a).

The phrase about 'the mud or the money' comes from T.W. Mapp. Torrens' Elusive Title: Basic Legal Principles of an Efficient Torrens' System. 1978, paragraph 4.24, and it is used extensively by the Scottish Law Commission in its report.

37 Land Registration etc. (Scotland) Act 2012, Section 77(1)(a).

38 Ibid., Section $78(\mathrm{~b})$.

39 BGB, Sections 883-888. See, for example, D. Assman. Die Vormerkung. Tübingen, Germany: Mohr Siebeck 1998.

40 Land Registration Act 2002, Section 72.
} 
insurance. A 'letter of obligation' is issued in this regard. In Scotland, independent notaries do not act in land transactions. Instead, there are simply solicitors acting for the seller and solicitors for the buyer. Concerns expressed by the Scottish legal profession as to whether insurance cover would continue to be available indefinitely on reasonable terms led the Scottish Law Commission to recommend the introduction of advance notices, described below.

When registered in the Land Register, these notices give protection for a period of 35 days. Take the following example. On day 1, Katri agrees to buy a piece of land from Peter. On day 2, she registers an advance notice in the Land Register. The next day, Peter fraudulently sells the same land to Kristina. On day 4, Peter grants a deed of transfer to Kristina, which she registers in the Land Register; then, on day 5, he grants a deed of transfer to Katri, which she registers in the Land Register. Under general principles of property law, Kristina 'wins' because she registered first. But because Katri has filed an advance notice, she becomes the owner upon registration of the deed of transfer on day 5. Similarly, Katri would prevail against any of Peter's creditors who try to execute diligence with respect to the land-i.e., who try to enforce any debts against the land in the time covered by the advance notice.

\section{Conclusions}

What are the lessons of the Scottish experience? First, land registration is a hugely important area of property law and critical in economic terms. Any reform of it needs to be carefully considered and given appropriate resources and time. Secondly, as always with law reform, comparative law must be drawn from and used appropriately. The mistake with the 1979 Act was to look only at English law. In the preparation of what is now the 2012 Act, the Scottish Law Commission rightly took a far broader approach. Thirdly, rules on land registration should be as consistent as possible with the underlying system of property law. Bijuralism should be rejected. The 2012 Act is a significant step forward for Scotland and to a certain extent makes our system closer to that in Estonia. 